\title{
A Framework for Research and Practice: Relationship among Mentoring, Power Distance Orientation and Innovative Behavior
}

\author{
Xiaowen He, Xiao Zhang \\ School of Business Administration, South China University of Technology, Guangdong, China \\ Email: verona.he@foxmail.com
}

Received 1 May 2015; accepted 22 June 2015; published 25 June 2015

Copyright (C 2015 by authors and Scientific Research Publishing Inc.

This work is licensed under the Creative Commons Attribution International License (CC BY). http://creativecommons.org/licenses/by/4.0/

(c) (i) Open Access

\begin{abstract}
It is the foundation to establish sustainable competition for enterprises that keep the ability to create and apply knowledge. As the value of knowledge is mainly instantiated in tacit knowledge, it is important for enterprises to increase the amount of tacit knowledge and apply it. Mentoring is one of typical models to implement knowledge socialization, which is given serious attention by scholars and entrepreneur. However, there is less research that takes cultural values into account when we discuss mentoring. Whether cultural values do influence the effect of implementing mentoring? In different countries, should we adjust measures to local conditions when enterprises implement mentoring? In the research, we theoretically discussed the relationship among mentoring, power distance orientation and innovative behavior, in which we also took psychological safety into account. Research results have indicated that mentoring is positively related to innovation behavior, in which perceived psychological safety plays a mediating role and power distance orientation plays a regulating role. What' more, protégés' power distance moderates the positive relationship between mentoring and innovation behavior in such a way that the relationship will be stronger for protégés who are lower rather than higher in power distance.
\end{abstract}

\section{Keywords}

Mentoring, Innovative Behavior, Psychological Safety, Power Distance

\section{Introduction}

Knowledge is the foundation to innovation, and innovation is a motivation to development [1]. Knowledge

How to cite this paper: He, X.W. and Zhang, X. (2015) A Framework for Research and Practice: Relationship among Mentoring, Power Distance Orientation and Innovative Behavior. Open Journal of Business and Management, 3, $250-256$. 
sharing among employees could improve innovation behavior [2]. As knowledge is the foundation of competitive advantage and expert power, people agree with the idea that knowledge is an exclusive domain and wouldn't want to share. There is a degree of difficulty to require employees to share knowledge. Based on commonly classification of knowledge, knowledge can be divided into explicit knowledge and tacit knowledge. Compared with explicit knowledge, tacit knowledge is more implicit, more personalized and difficult to imitate, which is more important to build core competitiveness [3]. According to The Knowledge-Creating Company, which was completed by Nonaka and Takeuchi in 1995, there are four models to transfer explicit knowledge and tacit knowledge, such as combination, internalization, externalization and socialization.

Mentoring is one of typical models to implement knowledge socialization, which is given serious attention by scholars and entrepreneurs. In western countries, enterprises use mentoring as a way to train new employees. More and more scholars become focused on the related problems of mentoring [4]. Other researches have shown that it is useful to improve employees' skills, performance and reduce staff turnover to implement mentoring. At the same time, mentor brings up protégé, which would help mentor get respect and identification from organizations, and would help them build their own social network. In general, mentors and protégés could get improvement through mentoring [5]. However, some enterprises in Asian such as China, mentoring does not play its expected effect. In China, some people agree with that the church disciples, starved master, so some mentor would not like to share knowledge with their protégés, which makes some enterprises in China ignore even had to give up mentoring [6].

Until now, most of the researches of mentoring are used western samples. It is doubt whether some existent researches would not be available in other culture scenes [7]. Previous researches mostly focused on how mentoring directly impacts on employees' performance and ignores to discuss its internal mechanism [8]. What's more, previous researches mostly focused on mentoring would improve employees' skills and help them success, and ignore to discuss mentoring would affect other behavior [9]. For example, by doing literature research in CNKI, we could only find 38 relevant researches about mentoring and most of them use qualitative research method, in which only five papers have done the empirical study [10]-[14]. Other scholars have done the research from the perspectives of mentor, protégés and organization, to find the main factors which would influence knowledge sharing between mentor and protégés, and try to discuss how the organization reward and mentor personality effect in the mentoring [15]. Whether cultural values do influence the effect of implementing mentoring? In different countries, should we adjust measures to local conditions when enterprises implement mentoring?

Other studies about mentoring and innovation behavior have shown that mentoring would be positive to share tacit knowledge, which is beneficial to improve creation in research [12]. However, theses researches are doing in western countries, which make people confused whether it would be available in other culture. Therefore, it is necessary to take culture variable into account.

In the research, we would analyze the relationship among mentoring, innovation behavior and psychological safety, in order to explain the mechanism between mentoring and innovation behavior. The atmosphere of psychological safety could promote employees to create. When employees feel psychological safety, they would be more willing to collect information and adopt new approaches to deal with problems. But there are less of researches discussing the relationship between mentoring and innovation behavior from the perspective of psychological safety.

Last but not least, many studies have shown that the difference in culture not only shows at the level of country and social, but also shows in the individual level. It means that different individuals in the same country may have different orientation in power distance [14], which would influence employees' attitude, cognition and behavior. Based on existing researches, we try to analyze how power distance plays its role in the relationship between mentoring and innovation behavior.

In short, we theoretically discussed the relationship among perceptions of mentor roles, power distance orientation and innovative behavior, in which we took psychological safety into account to analyze the relationship among the four variables.

\section{Method}

In order to achieve the objection of the research, we mainly use literature research method to do the study. Literature research mainly refers to do the research by collecting identifying the reorganizing existing literature, and then come up with a scientific cognition of the research topic. There are two aspects of the value of the literature research. One is that we can get new argument, new research perspective and new idea through doing the litera- 
ture research. The other is that we can get revelation and evidence for our view from the previous researches. In our study, we use literature method to collect relative previous research results, and then come up with the idea that power distance orientation as a regulated variable may influence the relationship between mentoring and innovation behavior. At the same time, we take psychological safety into account, in order to analyze the relationship among mentoring, innovation behavior and power distance orientation better.

\section{Research Model and Hypotheses Development}

\subsection{Mentoring and Protégés' Innovation Behavior}

Mentoring can be defined as a close interpersonal relationship between the senior managers or colleagues (mentor) and junior members or colleagues (protégés). Mentors provide three main functions, which include vocational support, role modeling and social support. The goal to provide vocational support is to improve protégés' skills for career development by providing sponsorship, exposure chances, coaching, protection and challenging assignments. The goal to provide social support is to improve protégés' competency and confidence by providing acceptance, counseling and friendship. Role modeling means that protégés imitate the behavior, skills and attitudes of mentors shown, and protégés learn how to deal with tasks and get confidence.

Innovation behavior can be defined that members in the organization put his new ideas about products, service and process into practice. Mentoring that is one of typical models to implement knowledge socialization could helpful to share tacit knowledge [12]. We do the analysis from these three functions. Firstly, if the mentor provides vocational support, protégés learn tacit knowledge from mentors by doing the challenging assignments or learning arranged by mentors. Knowledge sharing has a promote effect on innovation behavior [16]. Secondly, if the mentor provides social support, protégés perceive that they are cared and focused by mentors, which would help protégés feel psychological safety, realize the meaning of work and get confidence. As results, protégés get a high intrinsic motivation and willing to innovate [17]. Thirdly, if the mentor provide role modeling, protégés can be motivate by mentors’ hard-working and innovation behavior, which promote protégés imitate mentors to work hard and think more new ideas and put it into practice [18]. Based on the analysis above, we put forward the following hypothesis:

Hypothesis 1: Mentoring is positively related to protégés' innovation behavior.

\subsection{Mentoring and Protégés' Psychological Safety}

Kahn (1990) defined that psychological safety is a feeling of competence that member could show his image, position and career. Nembhard and Edmondson (2006) defined psychological safety once again that psychological safety is a common faith in a team, which means try to risk would be safe in the team [18]. In an environment that member feel psychological safety, members would not worry about punishment if they try to express a new idea, so members are more willing to think and express their new ideas, and even try their best to come up with creative ideas. Mentoring is helpful to increase protégés’ psychological safety [19]. We do the analysis from these three functions. Firstly, if mentors provide vocational support, mentors will improve protégés’ skills by teaching, which would reduce the possibility that protégés make mistakes [20]. What's more, mentor will arrange some challenging tasks for protégés and observe their performance. Based on their behavior, mentor will provide training and suggestions further, but not blame and punishment, which would improve protégés’ skills and make protégés feel that it is safe to make mistakes. Secondly, if mentors provide social support, the relationship between mentors and protégés would trust each other and friendly, which makes protégés more confident to face risk. When mentors provide social support, protégés will feel psychological safety and more willing to inquire, try and express his own ideas. Thirdly, if mentors provide role modeling, protégés will be more positive even that he makes a mistake, as protégés could get power form their mentors and believe they can do it well. Other studies have shown that supportive and coaching leaders is positively related to members' psychological safety. Based on the analysis above, we put forward the following hypothesis:

Hypothesis 2: Mentoring is positively related to protégés’ psychological safety.

\subsection{The Mediating Role of Psychological Safety}

Before employees decide whether to take an action or mark a decision, employees will weigh whether their decision would bring risk depent on the atmosphere in the organization. If employees think their trial would make 
them into risk, they would not do that [21]. For example, when a member came up with a new idea about product optimal design and before express the idea, he would judge whether his decision would affect his interpersonal relationship. If there is risk to share new ideas, he would not do that. It means members are more willing to create and express when they feel psychological safety. What's more, if members feel it is risk to innovate, they would be lazy to learn new skills, in which they have an idea that only operate and product by keeping the original state. Employees are more willing to come up with new ideas, express new ideas and create if they feel psychological safety. Based on the research done by Baer and Frese (2003), the atmosphere of psychological safety is positively related to innovation behavior [22]. Other studies have shown that the atmosphere of organization and team to make members feel psychological safety could promote members to create. Based on the analysis above, we put forward the following hypothesis:

Hypothesis 3: While employees feel psychological safety, employees would be more to innovate.

Other studies have shown that psychological safety could be a mediated variable to discuss innovation behavior. Wong, A. et al. (2010) have done a research and found that psychological safety plays a mediating effect in the relationship between leadership values and learning [23]. Post, C (2012) have done a research and found that psychological safety plays a mediating role in the relationship between deep-level team composition and innovation [24]. Lettieri, E. et al. (2012) have done a research and found that psychological safety plays a mediating role in the relationship between enacting risk-taking behavior and innovation [25]. Chen, C. et al. (2014) have done a research and found that psychological safety plays a mediating role in the relationship between formal mentoring and employees' attitude [26]. Mentor provides vocational support, role modeling and social support, which could improve protégés' skills and protect protégés when protégés make mistakes to a certain extent. These would make protégés feel psychological safety, which makes protégés more willing to come up with new ideas and express new ideas. Based on the analysis above, we put forward the following hypothesis:

Hypothesis 4: Psychological safety plays a mediating role in the relationship between mentoring and innovation behavior.

\subsection{The Moderating Role of Protégés' Power Distance Orientation}

To countries, power distance can be thought as a cultural context factor when doing researches [27]. To individual, power distance could be defined as the degree of acceptance when power distribute inequality in the organization [28]. Other studies have shown that power distance orientation would influence individual's attitude, cognition and behavior [29]. People with high power distance orientation would accept more social distance, more respect and be loyalty to authority.

According to cognitive appraisal theory, personal traits such as values would affect one's cognitive appraisal and affect one's behavior [30]. Many scholars focus on distance power. Though Hofstede the Dutch psychologist came up with the concept of cultural values which was based on the level of country and society, other studies have shown that the differences of cultural values also reflect on the level of individual. People come from the same country would have different cultural values [31]. As one aspect of cultural values, power distance orientation means the degree in which people would accept if feel unfair. Other studies have shown that power distance orientation would affect employees' attitude. Lin, W. et al. (2013) have done a research and found that power distance orientation plays a moderating effect in the relationship between abusive supervision and employee well-being [32]. Winkler, E. et al. (2014) have done a research and found that power distance orientation plays a moderating effect in leader behavior and subordinates' well-being [33]. In the research, we choose power distance orientation as moderated variable, as power distance orientation has closer collective with mentoring than other cultural values such as individual/collective [29]. At the same time, some scholars also focus on the characteristics of the power distance between mentors and protégés [34].

To people with high power distance orientation, people would show more respect, dependence and loyalty to authority, which prefer the leader style that leaders directly tell them how to do, but not for giving their chances to try or think by themselves [14]. In general, mentoring provide support and coaching, which aims to improve protégés' skills, so mentors prefer to challenge tasks and do not tell how to do directly [9]. In the case, protégés of high power distance orientation will be confused and disturbed because that they do not make sure how to do, so protégés will not feel psychological safety. On the contrary, protégés of low power distance orientation prefer to have more chances to try and do by their own way. In the case, mentor provide more challenge task for protégés to finish and guide them when they make mistakes, in which protégés feel psychological safety and more willing to express new ideas. 


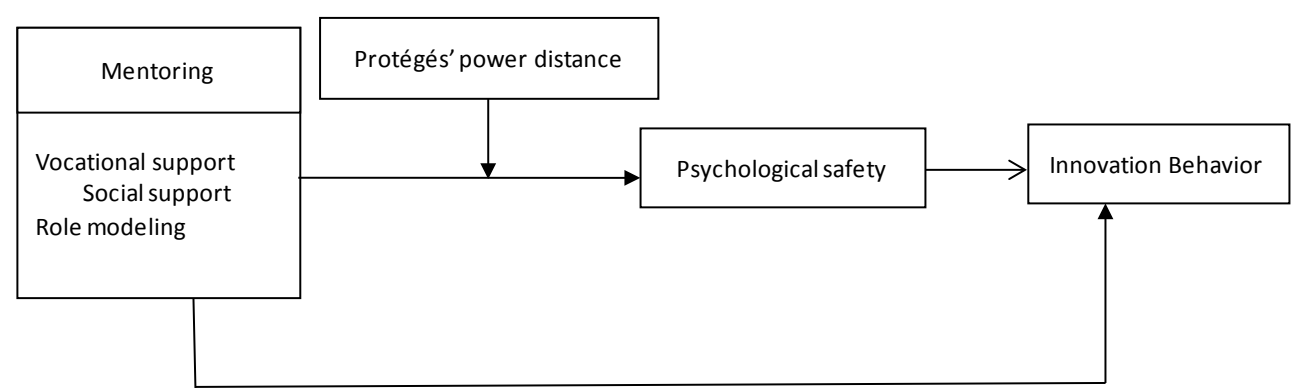

Figure 1. The researching framework among mentoring, innovation behavior, psychological safety and power distance orientation.

Hypothesis 5: Protégés' power distance moderates the positive relationship between mentoring and innovation behavior in such a way that the relationship will be stronger for protégés who are lower rather than higher in power distance.

\section{The Framework for Research}

Based on the analysis of precious researches, we put forward the researching framework among mentoring, innovation behavior, psychological safety and power distance orientation. As we can see in Figure 1, we put forward five hypothesizes in the research, which are 1) Mentoring is positively related to protégés' innovation behavior. 2) Mentoring is positively related to protégés’ psychological safety. 3) While employees feel psychological safety, employees would be more to innovate. 4) Psychological safety plays a mediating role in the relationship between mentoring and innovation behavior. 5) Protégés' power distance moderates the positive relationship between mentoring and innovation behavior in such a way that the relationship will be stronger for protégés who are lower rather than higher in power distance.

\section{Conclusion}

Knowledge is the foundation to innovation, and innovation is motivation to develop. As the value of knowledge is mainly instantiated in tacit knowledge, it is important for enterprises to increase the amount of tacit knowledge and apply it. Mentoring is one of typical models to implement knowledge socialization, which is given serious attention by scholars and entrepreneur. However, most of the researches of mentoring are used western samples. It is doubt whether some existent researches would not be available in other culture scenes. In the research, we mainly use literature research method to do the study. Research results have indicated that mentoring is positively related to innovation behavior, in which perceived psychological safety plays a mediating role and power distance orientation plays a regulating role. What' more, protégés' power distance moderates the positive relationship between mentoring and innovation behavior in such a way that the relationship will be stronger for protégés who are lower rather than higher in power distance. If all these hypotheses are true, enterprises implement mentoring in different cultural country, should adjust measures to local conditions. For example, for an IT company in China, if the company implements mentoring in order to encourage employees to share knowledge and innovate, it should choose the protégés of low power distance orientation, who prefers to this kind of management style. By learning from mentors, protégés feel psychological safety and are more willing to come up with new ideas and express their ideas. At the same time, the companies would create a freedom atmosphere by adjusting management system, in which employees feel that is safe to make risk and more willing to innovate. What's more, enterprises arrange training and coaching should take employees' power distance orientation into account, and different people may be suitable for different training style and leader style. At last, the limitation of the paper is without using empirical research method to verify hypothesis, and we will do that in the future.

\section{References}

[1] Wu, J.-L., Zhang, S., Shao, Z.-F. and Guang, M.A. (2015) Games Analysis and Simulation in Knowledge Sharing Based on Knowledge Contribution Assessment and Utility among Organization Employees. Journal of Industrial Engineering and Engineering Management, 1, 216-222.

[2] Zhang, J. (2007) A Research of How Social Capital Affect Employees’ Creativity. Zhejiang University, Hangzhou. 
[3] Polanyi, M. (1958) Personal Knowledge. The University of Chicago Press, Chicago, 15-51.

[4] Yang, Y. and Long, L.R. (2006) The Theory about the Mentoring Relationship in the Western. Advances in Psychological Science, 14, 450-455.

[5] Chen, C. (2009) An Empirical Analysis on Predictors of Mentors’ Knowledge Sharing Behaviors. Huazhong University of Science and Technology, Wuhan.

[6] Zhang, Z.T. (2008) Research on Mentoring. Foreign Economics \& Management, 5, 39-41.

[7] Bozionelos, N. (2006) Mentoring and Expressive Network Resources: Their Relationship with Career Success and Emotional Exhaustion among Hellenes Employees Involved in Emotion Work. The International Journal of Human Resource Management, 17, 362-378. http://dx.doi.org/10.1080/09585190500405009

[8] Pan, W., Sun, L. and Chow, I.H.S. (2011) The Impact of Supervisory Mentoring on Personal Learning and Career Outcomes: The Dual Moderating Effect of Self-Efficacy. Journal of Vocational Behavior, 78, 264-273. http://dx.doi.org/10.1016/j.jvb.2010.05.001

[9] Kwan, H.K., Liu, J. and Yim, F.H. (2011) Effects of Mentoring Functions on Receivers' Organizational Citizenship Behavior in a Chinese Context: A Two-Study Investigation. Journal of Business Research, 64, 363-370. http://dx.doi.org/10.1016/j.jbusres.2010.04.003

[10] Song, P.L. and Huang, X.Q. (2008) The Effect of Mentoring Relationship on Job Satisfaction, Organization Commitment and Turnover Intention-An Empirical Analysis in the Chinese Context. Economic Management, 21, 62-70.

[11] Zhou, X.H., Liu, B.J., Wu, X.N. and Jie, M.M. (2009) Study on the Effect of Mentoring Network on Employee’s Career Success. Journal of Management, 6, 1486-1491.

[12] Goffin, K. and Koners, U. (2011) Tacit Knowledge, Lessons Learnt, and New Product Development. Journal of Product Innovation Management, 28, 300-318. http://dx.doi.org/10.1111/j.1540-5885.2010.00798.x

[13] Kahn, W.A. (1990) Psychological Conditions of Personal Engagement and Disengagement at Work. Academy of management Journal, 33, 692-724. http://dx.doi.org/10.2307/256287

[14] Kirkman, B.L., Chen, G., Farh, J.L., Chen, Z.X. and Lowe, K.B. (2009) Individual Power Distance Orientation and Follower Reactions to Transformational Leaders: A Cross-Level, Cross-Cultural Examination. Academy of Management Journal, 52, 744-764. http://dx.doi.org/10.5465/AMJ.2009.43669971

[15] Chen, C. (2013) The Antecedents and Consequences of Mentoring in the Chinese Context. Ph.D. Thesis, Huazhong University of Science and Technology, Wuhan.

[16] Edmondson, A.C. (2002) The Local and Variegated Nature of Learning in Organization: A Group-Level Perspective. Organization Science, 13, 128-146. http://dx.doi.org/10.1287/orsc.13.2.128.530

[17] Wang, Y.-H., Hu, C.Y., Hurst, C.S. and Yang, C.-C. (2014) Antecedents and Outcomes of Career Plateaus: The Roles of Mentoring Others and Proactive Personality. Journal of Vocational Behavior, 85, 319-328. http://dx.doi.org/10.1016/j.jvb.2014.08.003

[18] Nembhard, I.M. and Edmondson, A.C. (2006) Make It Safe: The Effects of Leader Inclusiveness and Professional Status on Psychological Safe and Improvement Efforts in Health Care Teams. Journal of Organization Behavior, 27, 941966. http://dx.doi.org/10.1002/job.413

[19] Lu, L. and Liang, X.L. (2009) The Mediating Effect of Knowledge Sharing between Interpersonal Interactions and Innovation. Nankai Business Review, 12, 118-123.

[20] Vinarski-Peretz, H. and Carmeli, A. (2011) Linking Care Felt to Engagement in Innovative Behaviors in the Workplace: The Mediating Role of Psychological Conditions. Psychology of Aesthetics Creativity and the Arts, 5, 4353. http://dx.doi.org/10.1037/a0018241

[21] Liang, J., Farh, C. and Farh, J.L. (2008) Psychological Antecedents of Promotive and Prohibitive Voice Behavior: A Two-Wave Longitudinal Examination. Proceedings of the Third Conference of the International Association for Chinese Management Research, Guangzhou, 19-22 June 2008.

[22] Edmondson, A.C. (2002) The Local and Variegated Nature of Learning in Organization: A Group-Level Perspective. Organization Science, 13, 128-146. http://dx.doi.org/10.1287/orsc.13.2.128.530

[23] Wong, A., Tjosvold, D. and Lu, J. (2010) Leadership Values and Learning in China: The Mediating Role of Psychological Safety. Asia Pacific journal of Human Resources, 48, 86-107. http://dx.doi.org/10.1177/1038411109355374

[24] Post, C. (2012) Deep-Level Team Composition and Innovation: The Mediating Roles of Psychological Safety and Cooperative Learning. Group \& Organization Management, 37, 555-588. http://dx.doi.org/10.1177/1059601112456289

[25] Lettieri, E., Mura, M., Radaelli, G. and Spiller, N. (2012) Promoting Professionals’ Innovative Behaviors through Knowledge Assets: The Mediating Role of Knowledge Sharing and Psychological Safety. Proceedings of the Joint IFKADKCWS 2012: 7th International Forum on Knowledge Asset Dynamics and 5th Knowledge Cities World Summit: Knowledge, Innovation and Sustainability: Integrating Micro \& Macro Perspectives, Matera, 13-15 June 2012, 2282-2298. 
[26] Chen, C., Liao, J. and Wen, P. (2014) Why Does Formal Mentoring Matter? The Mediating Role of Psychological Safety and the Moderating Role of Power Distance Orientation in the Chinese Context. International Journal of Human Resource Management, 25, 1112-1130. http://dx.doi.org/10.1080/09585192.2013.816861

[27] Kirkman, B.L., Chen, G., Farh, J.L., Chen, Z.X. and Lowe, K.B. (2009) Individual Power Distance Orientation and Follower Reactions to Transformational Leaders: A Cross-Level, Cross-Cultural Examination. Academy of Management Journal, 52, 744-764. http://dx.doi.org/10.5465/AMJ.2009.43669971

[28] Lian, H., Lance Ferris, D. and Brown, D.J. (2012) Does Power Distance Exacerbate or Mitigate the Effects of Abusive Supervision? It Depends on the Outcome. Journal of Applied Psychology, 97, 107-123. http://dx.doi.org/10.1037/a0024610

[29] Khatri, N. (2009) Consequences of Power Distance in Organisations. Vision, 13, 1-9.

[30] Fischer, R. and Smith, P. (2006) Who Cares about Justice? The Moderating Effect of Values on the Link between Organizational Justice and Work Behavior. Applied Psychology: An International Review, 55, 541-562. http://dx.doi.org/10.1111/j.1464-0597.2006.00243.x

[31] Clugston, M., Howell, J.P. and Dorfinan, P.W. (2006) Does Cultural Socialization Predict Multiple Bases and Foci of Commitment? Journal of Management, 26, 5-30. http://dx.doi.org/10.1016/S0149-2063(99)00034-3

[32] Lin, W., Wang, L. and Chen, S. (2013) Abusive Supervision and Employee Well-Being: The Moderating Effect of Power Distance Orientation. Applied Psychology, 62, 308-329. http://dx.doi.org/10.1111/j.1464-0597.2012.00520.x

[33] Winkler, E., Busch, C., Clasen, J. and Vowinkel, J. (2014) Leadership Behavior as a Health-Promoting Resource for Workers in Low-Skilled Jobs and the Moderating Role of Power Distance Orientation. Zeitschrift für Personalforschung, 28, 96-116.

[34] Payne, S.C. and Huffinan, A.H. (2005) A Longitudinal Examination of the Influence of Mentoring on Organizational Commitment and Turnover. Academy of Management Journal, 48, 158-168. http://dx.doi.org/10.5465/AMJ.2005.15993166 